\title{
Образовна структура запослених У виСОКОшколСКИМ и универзитетским библиотекама Србије
}

\author{
Анђела Стошић \\ Универзитет у Београду \\ Филолошки факултет - Катедра за библиотекарство и информатику, Београд \\ andjela.stosic@fil.bg.ac.rs \\ Ана Ђорђевић \\ Универзитет у Београду \\ Хемијски факултет - Библиотека, Београд \\ anadj@chem.bg.ac.rs
}

\begin{abstract}
Сажетак
У раду се анализира структура запослених у универзитетским и високошколским библиотекама Републике Србије Подаци о степену и профилу образовања радника за 2018. и 2013. годину добијени су из базе Мрежа библиотека Србије. Они показују да у универзитетским библиотекама високообразовани посленици чине 63\% укупног броја радника. У високошколским библиотекама, које су у великом броју случајева библиотеке са једним запосленим, процентуално их је више, тачније 77\%. Библиотекари високошколских библиотека у 2018. години су, с обзиром на високошколску установу у којој раде, завршени факултет и смер на том факултету, сврстани у три групе: прву чине они који имају диплому из области библиотекарства и информатике (7,23\%), у другој су библиотекари који раде у библиотеци високошколске јединице чији се фонд односи на научне области које су и сами студирали (40\%), док трећој групи припадају библиотекари чије образовање није из области библиотекарства и информатике, нити из области којима је библиотека намењена (53\%). Универзитетске библиотеке несавесно достављају податке о образовном профилу својих запослених те се за њих није могла урадити никаква анализа, нити сазнати колико је библиотекара са дипломом из библиотечкоинформационих наука.
\end{abstract}

Кључне речи: високошколске библиотеке, универзитетске библиотеке, структура запослених, библиотекари, образовање, катедре за библиотекарство и информатику, Република Србија

\section{Увод}

Библиотеке високошколских установа пружају ослонац студентима, истраживачима, универзитетским сарадницима и наставницима у процесу учења и преношења знања те тако заједно доприносе јединственој мисији развоја науке.

Запослени у овим библиотекама обављају одговорне задатаке активно учествујући у формирању високообразованих стручњака који су носиоци развоја сваког друштва. Међу библиотечким радницима у овим установама налазе се људи различитих нивоа и профила образовања. Циљ овог рада је да детаљније сагледа њихову структуру. Истраживање образовне структуре кадра универзитетских и високошколских библиотека у Србији надовезује се на рад „Образовна структура запослених у јавним библиотекама Србије“, објављен у 35. броју Чишалишта и тиме употпуњује слику састава библиотечког кадра у нашој земљи. ${ }^{1}$ 
Када је реч о типовима библиотека у оквиру високошколских организација, најпре би требало напоменути да се, према Закону о високом образовању, у високошколске установе које обављају делатност високог образовања сврставају: универзитети, факултети (односно уметничке академије) у саставу универзитета, академије струковних студија, високе школе, као и високе школе струковних студија. Универзитет у свом саставу може имати и научне, односно уметничке институте ради унапређивања научноистраживачке, односно уметничко-истраживачке делатности. ${ }^{2}$ Закон о библиотечко-информационој делатности, на основу садржаја библиотечко-информационе грађе и извора и према профилу корисника, разликује појам високошколске библиотеке од појма универзитетских библиотека, затим библиотеке научноистраживачких института и установа од специјалних библиотека. Према овом акту, васпитнообразовне и научне установе су обавезне да организују прва три типа библиотека, којима су дужне да обезбеде све потребне услове за рад. Ове библиотеке се организују ради подршке и унапређења образовног, истраживачког и научног рада студената, наставника, професора и истраживача. Овде се издвајају универзитетске, као централне високошколске библиотеке које имају бројне дужности везане за успостављање функционалног библиотечко-информационог система на једном универзитету. ${ }^{3}$ За високошколске библиотеке у овом закону нема прецизнијих одредби, док се у Закону о високом образовању оне не спомињу, осим у члану 69 где се наводи да је оснивач дужан да високошколској установи обезбеди библиотечки фонд и у члану 40, у коме се каже да се докторске дисертације и извештаји комисије о њиховој оцени остављају у библиотеци ради увида јавности.

С друге стране, у Правилнику о националним стандардима за обављање библиотечко-информационе делатности, ${ }^{4}$ високошколске и универзитетске библиотеке појављују се као синтагма и имају јединствене стандарде, док су библиотеке научноистраживачких института и установа засебна тачка, па тако и специјалне библиотеке.

Подаци које су ауторке добиле о запосленима у универзитетским и високошколским библиотекама из базе Мрежа библиотека Србије (МБС $)^{5}$ обухватају универзитетске, високошколске (библиотеке високих школа, академија, факултетске, семинарске и сл.), али и библиотеке института и завода који се налазе у оквиру ових високошколских установа. Како последњи тип гравитира ка типу специјалних библиотека, подаци о њиховом кадру изузети су из анализе.

База МБС садржи, између осталог, податке о степену и профилу образовања запослених у универзитетским и високошколским библиотекама који би требало да буду погодни за статистичку обраду. Обухватност и тачност података зависи од савесности запослених у високошколским, као и у њиховим матичним библиотекама ${ }^{6}$ те због тога они не могу дати најјаснију слику структуре запослених у овим установама. У раду ће се показати да за поједине библиотеке нису унети подаци о профилу образовања за већину њихових запослених, што је, разуме се,

„Закон о високом образовању“, Службени іласник РС бр. 88 (2017), 73 (2018), 27 (2018), 67 (2019) и 6 (2020), члан 43 Високошколске установе.

„„Закон о библиотечко-информационој делатности“, Службени іласник Рейублике Србије бр. 52 (2011), преузето 10. 9. 2020, https://www.kultura.gov.rs/tekst/43/zakoni-i-uredbe.php.

${ }^{4}$ „Правилник о националним стандардима за обављање библиотечко-информационе делатности“, Службени іласник Рейублике Србијебр. 39 (2013),преузето 25. 8. 2020, https://www.pravno-informacioni-sistem.rs/SIGlasnikPortal/eli/rep/sgrs/ministarstva/ pravilnik/2013/39/1.

5 Увид у податке омогућила је Марина Митрић, дипломирани библиотекар-саветник. Ауторке јој се захваљују на професионалној помоћи и колегијалној сарадњи.

6 Матичне функције у универзитетским, високошколским и специјалним библиотекама научноистраживачких установа на територији АП Војводине обавља Библиотека Матице српске у Новом Саду, док је Универзитетска библиотека „Светозар Марковић” у Београду матична на територији централне Србије (град Београд и подручја Мачванског, Колубарског, Подунавског, Браничевског, Шумадијског, Поморавског, Борског, Зајечарског, Златиборског, Моравичког, Рашког, Расинског, Нишавског, Топличког, Пиротског, Јабланичког и Пчињског управног округа). Народна и универзитетска библиотека „Иво Андрић” у Приштини задужена је за територију АП Косова и Метохије. - Видети: „Решење о одређивању библиотека које обављају матичне функције у библиотечко-информационој делатности“, Службени іласник PC, број 122 (25. децембар 2012), преузето 16.8.2020, https://www.pravno-informacioni-sistem.rs/SIGlasnikPortal/viewdoc?uuid=4e965651-af62-4d2c-85b5-19a435d96ee2\&regactid=424323\&doctype=reg. 
Стошић А. и др. „Образовна структура запослених у високошколским и универзитетским библиотекама Србије“, 3-11

противно интересима библиотечко-информационе струке у Србији. Статистички подаци, како о запосленима, тако и о другим показатељима библиотечког пословања, које матичне библиотеке прикупљају путем анкете, ${ }^{7}$ служе да се анализирају стање, потребе и услови у библиотекама те дају предлози за унапређење рада, што је, због непотпуних података, тешко изводљиво. ${ }^{8}$

\section{Структура запослених према степену образовања}

У Републици Србији је у 2018. години било регистровано 215 високошколских библиотека9 и, према наводима Завода за статистику, у њима су радиле 544 особе. ${ }^{10}$ За базу МБС, податке о пословању доставило је 186 библиотека: 5 библиотека државних универзитета, ${ }^{11} 3$ библиотеке приватних универзитета, ${ }^{12} 11$ институтских и 167 осталих високошколских библиотека. ${ }^{13}$ Према њиховим извештајима, у универзитетским библиотекама је на стручним пословима радило 136 људи, ${ }^{14}$ у осталим високошколским библиотекама 391 лице. ${ }^{15}$ С обзиром на то да универзитетске библиотеке имају више функција, разнороднији и често обимнији фонд од оних на факултетима, академијама и високим школама, њихове структуре представљене су одвојеним графичким приказима (графички приказ 1 и графички приказ 2).

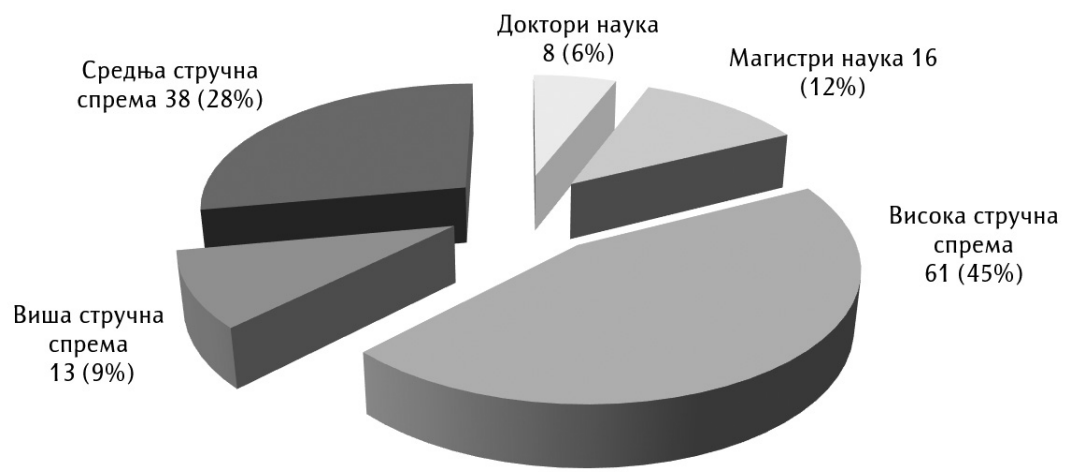

Графички приказ 1. Запослени у универзитетским библиотекама према степену образовања (2018)

\footnotetext{
7 Почев од 2020. године, традиционалне штампане Анкешее о библиоиечком йословању, које су библиотеке донедавно слале поштом, замењене су електронским.

8 Марина Митрић, „Зашто попуњавамо анкету о библиотечком пословању“, Школски библиоешекар (децембар 2011), преузето 1. 10. 2020, https://casopisbibliotekar.wordpress.com/2011/12/31/\%D0\%B7\%D0\%B0\%D1\%88\%D $1 \% 82 \% \mathrm{D} 0 \% \mathrm{BE}-\% \mathrm{D} 0 \% \mathrm{BF} \% \mathrm{D} 0$ \%BE\%D0\%BF\%D1\%83\%D1\%9A\%D0\%B0\%D0\%B2\%D0\%B0\%D0\%BC\%D0\%BE-\%D0\%B0\%D0\%BD\%D0\%BA\%D0\%B5\%D1\%82 \%D1\%83-\%D0\%BE-\%D0\%B1\%D0\%B8\%D0\%B1\%D0\%BB\%D0\%B8\%D0\%BE\%D1\%82\%D0\%B5\%D1\%87\%D0\%BA/.

9 Библиотека при високошколским установама.

10 Од тога је 535 запослених са пуним радим временом. - Републички завод за статистику и Завод за проучавање културног развитка, Кулйура, 2018 (Београд: Републички завод за статистику, 2019), 46-48, преузето 1. 9. 2020, https://publikacije.stat.gov. rs/G2019/Pdf/G20196010.pdf.

11 Податке доставиле: Универзитетска библиотека „Светозар Марковић“ у Београду, Универзитетска библиотека Крагујевац, Универзитетска библиотека „Никола Тесла“ Ниш, Централна библиотека Универзитета у Новом Саду и Библиотека Државног универзитета у Новом Пазару.

Према подацима Националног тела за акредитацију и проверу квалитета у високом образовању, у Републици Србији постоји 9 државних универзитета. - Национално тело за акредитацију и проверу квалитета у високом образовању, Нсхоgи акреguшаци-

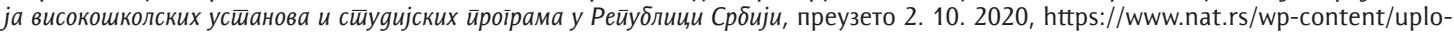
ads/2020/10/Ishodi-akreditacija-02.10.2020.pdf?script=cir.

12 Податке доставиле: Библиотека Универзитета Сингидунум и Библиотека Универзитета „Џон Незбит“. Универзитетска библиотека Нови Пазар приватни Универзитет доставила је податак да нема ниједног запосленог.

Према подацима Националног тела за акредитацију и проверу квалитета у високом образовању, у Републици Србији постоји 10 приватних универзитета.

13 За библиотеке са територије КиМ постоје само збирни подаци о броју запослених, без икаквих других детаља. У 2018. години је овде регистровано 10 библиотека са укупно 15 запослених. Податке је прикупила и доставила НУБ „Иво Андрић“, Приштина.

${ }^{14}$ Са пуним радним временом 134

15 Са пуним радним временом 371
} 
Стошић А. и др. „Образовна структура запослених у високошколским и универзитетским библиотекама Србије“, 3-11

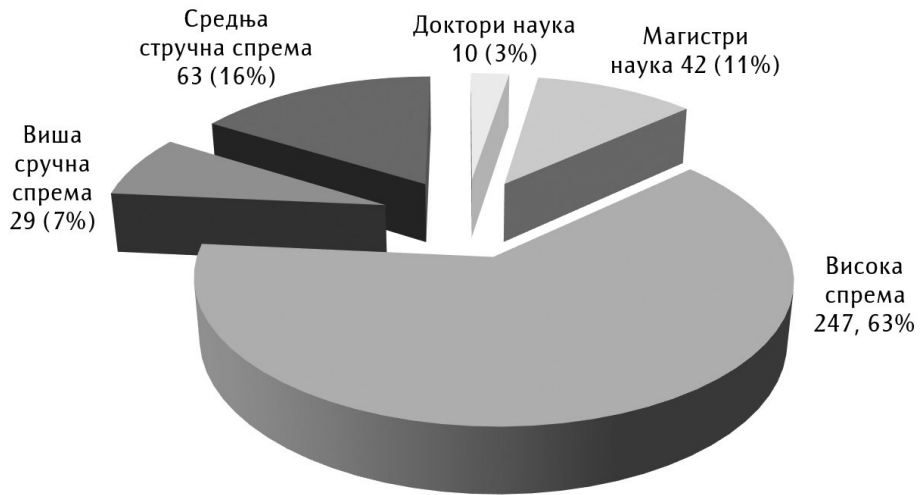

Графички приказ 2. Запослени у високошколским библиотекама према степену образовања (2018)

Као што се на графичким приказима и види, универзитетски образовани кадар чини изразиту већину у библиотекама високошколских установа, што је и логично, ако се има у виду да су то библиотеке које нуде врхунску научно-образовну литературу и које су намењене управо најобразованијим члановима друштва, односно онима који то желе да постану.

На првом графичком приказу се може видети да високообразовани посленици у универзитетским библиотекама чине $63 \%$ стручног особља. ${ }^{16}$ У високошколским библиотекама, које су у великом броју случајева библиотеке са једним запосленим, процентуално их је више, тачније 77\% (графички приказ 2). Запослени са вишом стручном спремом чине мање од десетине свих радника, што је и разумљиво, ако се узме у обзир да тај степен образовања више није могуће стећи, а да постојећи кадар приводи крају свој радни век. Радници са средњим образовањем процентуално су заступљенији у универзитетским библиотекама, које по правилу имају сложенију организациону структуру, стога и потребу за већим бројем манипуланата. ${ }^{17}$

Рад „Образовна структура запослених у јавним библиотекама Србије“, који се бавио анализом структуре кадра у јавним библиотекама, показао је да последњих година постоје значајне промене када је у питању однос високообразованог и средњошколског кадра и то у корист првог. ${ }^{18}$ Оваква тенденција уочава се и код високошколских и универзитетских библиотека. У високошколским библиотекама је, 2018. године, са средњом стручном спремом било 16\% радника, док их је пет година раније процентуално било више - 20\% (графички приказ 3). Запослени са високим образовањем ${ }^{19}$ су у високошколским библиотекама 2013. чинили 73\%, а у 2018. чак 77\% од укупног броја радника. Повећање заступљености високообразованих посленика евидентно је и у универзитетским библиотекама - са 60\% у 2013, на 63\% у 2018. (графички приказ 4).

\footnotetext{
16 Уколико узмемо у обзир и магистре и докторе наука.

17 Највећа универзитетска библиотека у Србији је Универзитетска библиотека „Светозар Марковић“ у Београду, са више од 80 запослених. Универзитетска библиотека „Никола Тесла“ Ниш има укупно 23, а Универзитетска библиотека Крагујевац 17 радника. Библиотека државног универзитета у Новом Пазару запошљава 5 лица. Централна библиотека Универзитета у Новом Саду има два запослена, од тога је један са пуним радним временом. Библиотека Универзитета Сингидунум има три, а Библиотека Универзитета "Џон Незбит" два запослена.

18 Стошић и Ђорђевић: 4.

19 Укључујући и докторе и магистре наука.
} 
Стошић А. и др. „Образовна структура запослених у високошколским и универзитетским библиотекама Србије“, 3-11

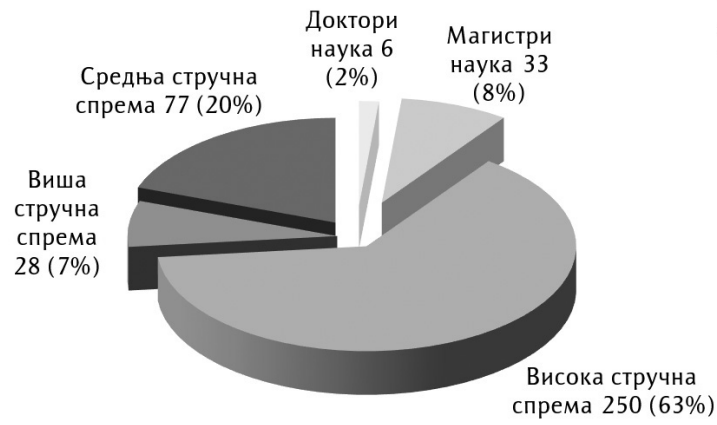

Графички приказ 3. Запослени у високошколским библиотекама у 2013.

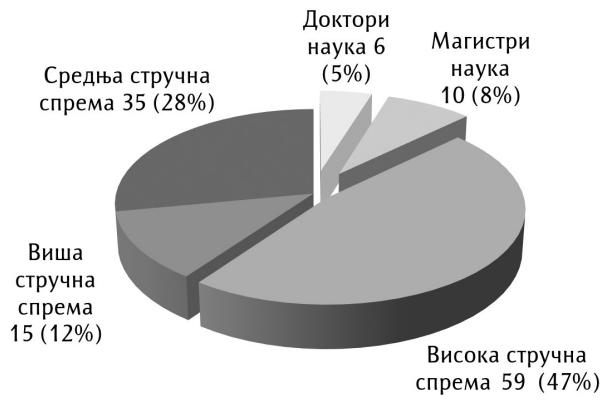

Графички приказ 4. Запослени у универзитетским библиотекама у 2013.

\section{Образовни профили запослених}

Високошколске библиотеке се, у зависности од појединачних прописа институција у којима се налазе, сматрају организационим јединицама научноистраживачког типа, стручним службама, па и јединицама секретаријата факултета. ${ }^{20}$ Рад ових библиотека уређује се законима из области библиотечко-информационе делатности, високог образовања, затим статутима и другим актима високошколских установа. Библиотеке функционишу према својим правилницима, који се такође разликују од једне до друге институције. Према стандардима за акредитацију, за извођење једног студијског програма, високошколска установа мора да обезбеди библиотечки простор, читаоницу и најмање 100 релевантних библиотечких јединица. Библиотека на високошколској установи има најмање 1000 јединица библиотечке грађе, које се односе на наставни програм и једног библиотекара. ${ }^{21}$

Правилници о систематизацији послова у институцијама високог образовања могу да пропишу степен образовања потребан за свако радно место, па и факултетску спрему, односно студијски профил који је за то место потребан, што углавном и чине, осим када су у питању библиотеке. За позицију дипломираног библиотекара је, најчешће, потребно да, уз високу стручну спрему, запослени поседује положен стручни испит, што је у складу са оним што прописује 3акон о библиотечко-информационој делатности.Уз то се ослањају на оно што је прописано Правилником о националним стандардима за обављање библиотечко-информационе делатности који каже да „стручне послове у високошколској и универзитетској библиотеци обављају запослени:

1) са високим стручним образовањем: дипломирани библиотекари ${ }^{22}$ и библиотекари [...] $]^{23}$

2) са вишим стручним образовањем: виши књижничар;

3) са средњим стручним образовањем: књижничари и књиговесци. “24

20 Према Статуту Економског факултета у Београду, Библиотека је једна од стручних служби Факултета. Статут Правног факултета у Београду своју Библиотеку сврстава у научноистраживачке јединице. - Видети: „Статут Универзитета у Београду - Правног факултета" (2018), преузето 25.9.2020, http://www.ius.bg.ac.rs/statut/Statut\%20Fakulteta\%202018\%20kona\%C4\%8Dna\%20 verzija\%2021.4.\%202018.pdf и „Статут Универзитета у Београду - Економског факултета“ (2018), преузето 25. 9. 2020, http:// www.ekof.bg.ac.rs/wp-content/uploads/2014/04/Statut-Univerziteta-u-Beogradu-Ekonomskog-fakulteta-sa-izmenama-i-dopunama.pdf.

${ }_{21}$ Министарство просвете, науке и технолошког развоја Републике Србије, „Правилник и стандарди за почетну акредитацију високошколских установа и студијских програма“, преузето 15. 9. 2020, http://www.mpn.gov.rs/wp-content/uploads/2015/09/ Pravilnik-i-standardi-za-pocetnu-akreditaciju-ustanove-i-programa.pdf.

22 Према Закону о библиотечко-информационој делатности, звање „дипломирани библиотекар“ додељују Народна библиотека Србије и Библиотека Матице српске, које нису високошколске установе.

${ }^{23}$ Или одговарајуће послове обављају дипломирани библиограф, дипломирани археограф, дипломирани информатор, дипломирани документалист, дипломирани конзерватор и дипломирани информатичар, библиограф, археографи, информатор, документалист и конзерватор;

24 „Правилник о националним стандардима за обављање библиотечко-информационе делатности“. 
На веб-страници Заједнице библиотека универзитетета Србије постоји предлог Стандарда за високошколске библиотеке који су мало прецизнији када кажу да „у библиотекама високошколских установа раде квалификовани стручњаци за библиотечко-информациону делатност - библиотекари са положеним стручним библиотекарским испитом и стеченим вишим стручним звањима, књижничари и информатички стручњаци одговарајућих профила." ${ }^{25}$ Међутим, како је према Закону о библиотечко-информационој делатности за послове дипломираног библиотекара квалификован свако ко има диплому о стеченом високом образовању, ни такав стандард не би ништа променио.

Америчко удружење библиотекара је још пре више од 30 година усвојило Стандарде за универзитетске библиотеке (Standards for university libraries: Evaluation of performance) који говоре оно што ми не успевамо да кажемо ни дан-данас - да би библиотекари морали да имају одговарајуће образовање из библиотечко-информационих наука, а онда и из других дисциплина како би омогућили укљученост библиотеке у академске програме универзитета. ${ }^{26}$ Резултат тога био је да су професионални библиотекари-информатичари пре десетак година у америчким библиотекама чинили трећину свих запослених у библиотекама, што је за српске библиотечке кругове непојмљиво ${ }^{27}$

Састав запослених са високим образовањем у библиотекама факултета, академија и високих школа анализиран је према образовном профилу. Како је свака високошколска библиотека специјализована за одређену област знања, оне се међусобно прилично разликују по садржини фонда, није било смислено тражити најдоминантнију струку међу њиховим библиотекарима јер је постојала претпоставка да она у великој мери зависи од научних области које се на високошколској установа изучавају. Стога су библиотекари високошколских библиотека, с обзиром на високошколску установу у којој раде, завршени факултет и смер на том факултету, сврстани у три групе: прву чине они који имају диплому из области библиотекарства и информатике, у другој су библиотекари који раде у библиотеци високошколске јединице чији се фонд односи на научне области које су и сами студирали, док трећој групи припадају библиотекари чије образовање није из области библиотекарства и информатике, нити из области којима је библиотека намењена.

Од укупно 299 високообразованих лица која су у 2018. години радила у високошколским библиотекама Србије, ${ }^{28} 249$ (83,3\%) је доставило податке о завршеном факултету. ${ }^{29}$ Међу њима је 18 (7,23\%) библиотекара-информатичара, од којих само један ради на Филолошком факултету. Филолози се у овим библиотекама, као и у јавним, издвајају као најбројнија групација која чини готово петину свих радника са високим образовањем. ${ }^{30}$ Запослених који раде у високошколским библиотекама чији фондови спадају у научне области из којих су стекли

\footnotetext{
25 Заједница библиотека универзитета Србије, „Стандарди за високошколске библиотеке“ (2012), преузето 26. 9. 2020. https:// zbus.rs/wp-content/uploads/2016/03/Standardi-za-visokoskolske-2012.pdf.

26 "Standards for university libraries: Evaluation of performance", ACRL College \& Research Libraries Newsvol. 49, No 6 (1988), preuzeto 26. 9. 2020, https://crln.acrl.org/index.php/crlnews/article/view/21603/27057.

27 Гордана Стокић, „Како да постанем библиотекар?“, Паниевачко иишалищше бр. 16 (мај 2010): 1, преузето 13. 10. 2020, http:// www.citaliste.com/casopis/br16/Uvodnik.pdf.

28 У збир улази 10 доктора наука и 42 магистра.

${ }^{29}$ Није могуће прецизно навести који је број запослених у универзитетским, а који у високошколским библиотекама. Колико су статистички подаци који се о запосленима у библиотекама прикупљају неусаглашени и стога неинформативни, може се илустровати примером Универзитетске библиотеке „Светозар Марковић“ у Београду. У колони табеле која показује укупан број запослених са пуним радним временом у једној библиотеци стоји број 84. Међутим, уколико се саберу бројеви који говоре о укупном броју запослених са високом, вишом, средњом стручном спремом, магистратуром и докторатом, у истој табели, тај број је 88. У случају да се разјашњење ове ситуације потражи у табели у којој стоје подаци о запосленима понаособ (библиотека у којој је запослен, степен и профил образовања, стручни испит) тамо се име Универзитетске библиотеке понавља 72 пута, што значи да је то број њених запослених, односно број стручних радника за које је доставила податке што би, наравно требало да буде еквивалентно укупном броју запослених на стручним пословима. Уколико је неко заинтересован за ову нелогичност, он се, наравно, може обратити овој јавној високошколској установи и распитати се о броју њених запослених, али се онда поставља питање: Чему служи оваква статистика?

30 Укупно 60 филолога.
} 
Стошић А. и др. „Образовна структура запослених у високошколским и универзитетским библиотекама Србије“, 3-11

диплому укупно је 99, односно 40\%. Оних који раде у високошколским библиотекама које се не односе на научне области које су проучавали на студијама има 132, тј. 53\%.

Ипак, може се рећи да постоји помак када се ради о броју дипломираних библиотекараинформатичара јер подаци за 2013. годину показују да их је у високошколским библиотекама било тек шесторо међу 217 високообразованих.

Када су у питању запослени са вишом стручном спремом у 2018. години, од њих 17 за колико су подаци достављени, 11 ради у библиотекама из области за које су се образовали, а шесторо њих ради у библиотекама које су такорећи ван њихове струке. Међу 49 радника са средњом стручном спремом у високошколским библиотекама налази се чак 12 оних који су завршили средњу библиотекарску школу.

О образовном профилу запослених у универзитетским библиотекама готово да нема података у бази Мрежа библиотека Србије. Универзитетска библиотека „Светозар Марковић“, која је матична за све високошколске библиотеке централне Србије и стога надлежна за прикупљање података о њиховом пословању, доставила је податак о завршеном факултету за једног свог запосленог у 2018. години. Остале универзитетске библиотеке спорадично су обавиле ову дужност. ${ }^{31}$ У бази постоји 26 лица са информацијом о завршеној школи/факултету. Међу њима је двоје са средњом библиотекарском школом и шесторо са другим средњошколским образовањем. Од 17 библиотекара са високим образовањем, један је са дипломом из библиотечко-информационих наука.

Наведени подаци индиректно говоре да не постоји свест о улози библиотека, па самим тим ни њихових библиотекара, у високошколском образовању, иако истраживања јасно указују на директну корелацију између броја библиотекара и успешности студената и истраживача у високошколским установама. ${ }^{32}$ Наравно, она подразумевају да су библиотекари људи који су образовани да се баве организацијом знања, проналажењем и евалуацијом информација, који су стекли способности да користе информационо-комуникационе технологије и да се сналазе у огромним базама података те да са таквим компетенцијама студентима и научним радницима омогуће једноставније истраживање и учење.

\section{Закључак}

Библиотеке би требало да буду партнери високошколских установа који процес образовања и научног развоја чине успешнијим. Због тога је њихово особље претежно високообразовано и чини више од 60\% укупног броја запослених у универзитетским библиотекама, а у високошколским преко 3/4. Ипак, показало се да се о овом кадру не брине превише: универзитетске библиотеке се несавесно односе према вођењу библиотечке статистике и на тај начин отежавају анализу стања, а индиректно и унапређење библиотечко-информационе делатности; већина библиотекара у високошколске библиотеке долази са образовањем које је минимално, или чак нимало повезано са оним чиме ће се у библиотеци бавити. То не мора да значи да свој посао не раде добро, али је сигурно да им је потребно више времена и труда у овладавању библиотечко-информационим знањима и вештинама.

\footnotetext{
31 Универзитетска библиотека Крагујевац навела је податке за шесторо од укупно 17 радника. Универзитетска библиотека „Никола Тесла“ Ниш то је учинила за 14, од укупно 23 запослена. Централна библиотека Универзитета у Новом Саду доставила је податке за оба своја запослена. Библиотека државног универзитета у Новом Пазару доставила је податак за једног од пет чланова особља. Библиотека Универзитета Сингидунум навела је образовни профил за једног од три радника. Библиотека Универзитета "Џон Незбит“ такође је доставила податак за једног запосленог.

32 IFLA Library Policy and Advocacy Blog, "Library Stat of the Week \#30: Countries with more librarians per student tend to have higher completion rates", preuzeto 15.7.2020, https://blogs.ifla.org/lpa/2020/08/03/library-stat-of-the-week-30-countries-with-more-librarians-per-student-tend-to-have-higher-completion-rates/?fbclid=IwAR2FqNwpyzCnchI4FGhVIwk95Q2OihXyH6qsNhiAvgIYfeGk1rDH6K6QFo.
} 
Стошић А. и др. „Образовна структура запослених у високошколским и универзитетским библиотекама Србије“, 3-11

Доступни подаци показују да у високошколским библиотекама ради занемарљив број дипломаца катедара за библиотекарство и информатику те они чине нешто више од 7\% високообразованог кадра у 2018, мада се њихов број повећао у односу на 2013. годину, када нису чинили ни цела 3 процента. На руку им не иду постојећа законска регулатива и стандарди.

\section{Литература и извори:}

1. IFLA Library Policy and Advocacy Blog."Library Stat of the Week \#30: Countries with more librarians per student tend to have higher completion rates". Preuzeto 15. 7. 2020. https:// blogs.ifla.org/lpa/2020/08/03/library-stat-of-the-week-30-countries-with-more-librariansper-student-tend-to-have-higher-completion-rates/?fbclid=IwAR2FqNwpyzCnchI4FGhVIwk9 5Q2Oih-XyH6qsNhiAvgIYfeGk1rDH6K6QFo.

2. Ministarstvo prosvete, nauke i tehnološkog razvoja Republike Srbije. „Pravilnik i standardi za početnu akreditaciju visokoškolskih ustanova i studijskih programa“ (2013). Preuzeto 15. 9. 2020. http://www. mpn.gov.rs/wp-content/uploads/2015/09/Pravilnik-i-standardi-za-pocetnu-akreditaciju-ustanove-iprograma.pdf.

3. Mitrić, Marina. "Zašto popunjavamo anketu o bibliotečkom poslovanju“. Školski bibliotekar (decembar 2011). Preuzeto 1. 10. 2020. https://casopisbibliotekar.wordpress.com/2011/12/31/\%D0\%B7\%D0\%B0 \%D1\%88\%D1\%82\%D0\%BE-\%D0\%BF\%D0\%BE\%D0\%BF\%D1\%83\%D1\%9A\%D0\%B0\%D0\%B2\%D0\% B0\%D0\%BC\%D0\%BE-\%D0\%B0\%D0\%BD\%D0\%BA\%D0\%B5\%D1\%82\%D1\%83-\%D0\%BE-\%D0\%B1\% D0\%B8\%D0\%B1\%D0\%BB\%D0\%B8\%D0\%BE\%D1\%82\%D0\%B5\%D1\%87\%D0\%BA/.

4. Nacionalno telo za akreditaciju i proveru kvaliteta u visokom obrazovanju, Ishodi akreditacija visokoškolskih ustanova i studijskih programa u Republici Srbiji.Preuzeto 2. 10. 2020. https://www.nat.rs/ wp-content/uploads/2020/10/Ishodi-akreditacija-02.10.2020.pdf?script=cir.

5. „Pravilnik o nacionalnim standardima za obavljanje bibliotečko-informacione delatnosti“. Službeni glasnik RS broj 39 (2013). Preuzeto 25. 8. 2020. https://www.pravno-informacioni-sistem.rs/ SIGlasnikPortal/eli/rep/sgrs/ministarstva/pravilnik/2013/39/1.

6. Republički zavod za statistiku i Zavod za proučavanje kulturnog razvitka. Kultura, 2018. Beograd: Republički zavod za statistiku, 2019. Preuzeto 1. 9. 2020. https://publikacije.stat.gov.rs/G2019/Pdf/ G20196010.pdf.

7. "Rešenje o određivanju biblioteka koje obavljaju matične funkcije u bibliotečko-informacionoj delatnosti“. Službeni glasnik RS br. 122 (25. decembar 2012). Preuzeto 16. 8. 2020. https://www.pravnoinformacioni-sistem.rs/SIGlasnikPortal/viewdoc?uuid=4e965651-af62-4d2c-85b5-19a435d96ee2\&reg actid $=424323 \&$ doctype $=$ reg.

8. "Standards for university libraries: Evaluation of performance". ACRL College \& Research Libraries Newsvol. 49, No 6 (1988).Preuzeto 26. 9. 2020.https://crln.acrl.org/index.php/crlnews/article/ view/21603/27057.

9. "Statut Univerziteta u Beogradu - Ekonomskog fakulteta“ (2018). Preuzeto 25. 9. 2020. http://www. ekof.bg.ac.rs/wp-content/uploads/2014/04/Statut-Univerziteta-u-Beogradu-Ekonomskog-fakultetasa-izmenama-i-dopunama.pdf.

10. "Statut Univerziteta u Beogradu - Pravnog fakulteta“ (2018). Preuzeto 25. 9. 2020. http://www.ius. bg.ac.rs/statut/Statut\%20Fakulteta\%202018\%20kona\%C4\%8Dna\%20verzija\%2021.4.\%202018.pdf.

11. Stokić, Gordana. "Kako da postanem bibliotekar?“. Pančevačko čitalište br. 16 (maj 2010): 1. Preuzeto 13. 10. 2020. http://www.citaliste.com/casopis/br16/Uvodnik.pdf.

12. Stošić, Anđela i Ana Đorđević. „Obrazovna struktura zaposlenih u javnim bibliotekama Srbije“. Čitalište: naučni časopis za teoriju i praksu bibliotekarstva god. XVIII, br. 35 (novembar 2019): 2-9. 
Стошић А. и др. „Образовна структура запослених у високошколским и универзитетским библиотекама Србије“, 3-11

13. Zajednica biblioteka univerziteta Srbije. „Standardi za visokoškolske biblioteke“ (2012). Preuzeto 26.

9. 2020. https://zbus.rs/wp-content/uploads/2016/03/Standardi-za-visokoskolske-2012.pdf.

14. „Zakon o bibliotečko-informacionoj delatnosti“. Službeni glasnik Republike Srbije br. 52 (2011). Preuzeto 10. 9. 2020. https://www.kultura.gov.rs/tekst/43/zakoni-i-uredbe.php.

15. „Zakon o visokom obrazovanju“. Službeni glasnik RS br. 88 (2017), 73 (2018), 27 (2018), 67 (2019)

i 6 (2020). Preuzeto 16. 8. 2020. http://www.pravno-informacioni-sistem.rs/SIGlasnikPortal/ viewdoc?uuid=e1a4feea-89d9-40b9-869e-911a3a6f18c8\&regactid=429768\&doctype=reg.

\title{
Educational Structure of Employees in Serbian Academic Libraries
}

\begin{abstract}
Summary
The paper analyzes the structure of employees in libraries attached to higher education institutions of the Republic of Serbia. Data on the level and profile of employee education for 2018 and 2013 were obtained from the Library Network of Serbia database. They show that in university libraries, highly educated employees make up $63 \%$ of the total number of employees. In the rest of the libraries that belong to the higher education institutions, which are mostly libraries with one employee, there are more of them (77\%). Based on the data for 2018, considering the higher education institution in which they work, and the faculty they graduated from, the librarians of the libraries that belong to the higher education institutions are classified into three groups: the first group consists of LIS graduates (7.23\%), the second group includes librarians working in libraries of higher education units whose funds refer to scientific fields that they themselves studied (40\%), while the third group includes librarians who are neither LIS graduates nor educated in the field for which the library is intended (53\%). University libraries submit data on the educational profile of their employees irregularly, which has made the research of the professional structure of librarians in these institutions impossible.

Keywords: academic libraries, educational structure of employees, librarians, education, LIS departments, Republic of Serbia
\end{abstract}



International License. 